\title{
Case Studies of Comprehensive Gas Control Method during Fully Mechanized Caving of Low-Permeability Ultrathick Coal Seams
}

\author{
Bangyou Jiang $\mathbb{D}^{1}$, Shitan Gu $\mathbb{D}^{1},{ }^{1}$ Wenshuai Li $\mathbb{D},{ }^{2}$ Guangchao Zhang, ${ }^{1}$ and Jihua Zhang ${ }^{3}$ \\ ${ }^{1}$ State Key Laboratory of Mining Disaster Prevention and Control Co-Founded by Shandong Province and the Ministry of Science \\ and Technology, Shandong University of Science and Technology, Qingdao 266590, China \\ ${ }^{2}$ Shandong Provincial Key Laboratory of Civil Engineering Disaster Prevention and Mitigation, Shandong University of Science \\ and Technology, Qingdao 266590, China \\ ${ }^{3}$ Faculty of Architecture and Civil Engineering, Huaiyin Institute of Technology, Huai'an, Jiangsu 223001, China
}

Correspondence should be addressed to Shitan Gu; chinasdgst@163.com and Wenshuai Li; lwsnote@163.com

Received 17 February 2021; Accepted 10 July 2021; Published 22 July 2021

Academic Editor: Yi Xue

Copyright (C) 2021 Bangyou Jiang et al. This is an open access article distributed under the Creative Commons Attribution License, which permits unrestricted use, distribution, and reproduction in any medium, provided the original work is properly cited.

\begin{abstract}
Slicing fully mechanized caving mining is a standard high-efficiency mining method for ultrathick coal seams. However, the effectiveness of gas control has accentuated the difficulty in fully mechanized top coal caving of low-permeability ultrathick coal seams. This study focused on mining the No. 9-15 coal in Liuhuanggou Coal Mine, Xinjiang Province, China. To this aim, the results of theoretical analyses and field tests were combined to explore a comprehensive gas control method for fully mechanized caving of low-permeability ultrathick coal seams. The No. (9-15)06 panel was a top-slicing panel of the No. 9-15 coal with a mining height of $9 \mathrm{~m}$. Gas analysis results revealed that gas emissions in the No. (9-15)06 panel are mainly sourced from the coal wall, caving top coal, goaf, and neighboring coal seams. Based on gas source separation, a comprehensive gas control method was proposed. The proposed method was based on the combination of gas predrainage alongside the coal seam, high-position drilling on the top, preburial of pipes in the goaf, and pressure-balancing ventilation. The permeability and gas predrainage were enhanced by hydraulic fracturing in low-permeability coal seams. According to the characterizations of coal seam and crustal stress distribution, the arrangement of the boreholes and backward-segmented fracturing technology were designed. From the field results, the coal seam presented a remarkable prefracturing under hydraulic fracturing. Besides, the mean gas predrainage from the boreholes was enhanced by four times compared to the prehydraulic fracturing state. Finally, using the proposed comprehensive control method based on the gas sources, field tests were performed in the No. (9-15)06 panel. The measured results demonstrated that gas concentration in the return airflow is fluctuated within a range of $0.05 \%$ to $0.35 \%$. The proposed gas control method can provide an insightful reference for other similar projects.
\end{abstract}

\section{Introduction}

Slicing fully mechanized mining is a high-efficiency mining method for ultrathick seams in China. However, most of China's coal fields include high gas and low permeability [1, 2]. Ultrathick seams with low permeability are commonly deficient in gas predrainage. When using the fully mechanized mining method, a significant amount of gas is emitted from coal seams. The high concentration and accumulation of gas in fractures can easily trigger a formidable accident such as a gas explosion in the overlying strata of the goaf and threaten production safety in the mines $[3,4]$. Numerous attempts have been made to develop useful gas drainage and discharge methods and achieve adequate gas control by the fully mechanized mining of low-permeability ultrathick coal seams.

Fan and Wang focused on fully mechanized mining of ultrathick mines in Tashan Mine and proposed the gas in the goaf can be controlled by combining vertical surface drilling and high-position gas drainage roadways [5]. However, for the mines with great burial depth, the cost of gas drainage by drilling a significant number of vertical holes is high. According to the characteristics of longwall coal mining in Australia, Guo et al. projected a gas drainage and discharge 
method for the goaf using horizontal drilling [6]. They exhibited a good drilling operation in the construction of the roof fracturing zone. Furthermore, Zhang et al. examined the development rules for the roof fracturing zone when using high-dipping longwall coal caving and the related effect on gas drainage [7]. They designed an optimal construction layer during high-position drilling for gas drainage and discharged from the No. 704 panel of Baojishan Mine [7]. Moreover, Liu addressed gas accumulation at the upper corner of the goaf in a fully mechanized panel for tilted ultrathick coal seams [8]. This technique was successfully applied in Wudong Mine [8] by preburying gas drainage and discharge pipes in the goaf.

In previous studies, a straight-line construction was performed for gas drainage in surface and underground drilling operations. Recently, new means of gas drainage are provided by directional drilling in coal mines. In this regard, boreholes can be drilled in coal seams along with a preset direction [9]. Taking Daning Mine, Shanzi, China, as an example, Lu et al. carried out the directional drilling in coal seams for gas predrainage and achieved favorable results [10]. Li et al. proposed a new inverse $\pi$-type drilling mode for gas drainage and discharge and realized the gas comprehensively controlled through passing the caving zone, fracture zone, and coal seams in the working face [11]. In contrast to traditional drilling, the directional drilling of the coal seam exhibits a series of advantages, including strong adaptability, high drilling proportion, and good efficiency of gas drainage. Although these advantages are appropriate to gas control in directional drilling of coal seams, they should be pretty permeable.

For low-permeability coal seams, drilling alongside the coal seam has a poor gas drainage performance; therefore, some fracturing techniques are necessary for prefracturing in coal seams and enhancing their permeability. Deep-hole loosening blasting is a common prefracturing technique in coal seams $[12,13]$. However, this technique has certain shortcomings. The dynamic shock wave produced in the deep-hole blasting can easily damage the surrounding rocks in the tunnel and lead to more difficulty controlling the rock deformation. Also, unreasonable deep-hole blasting schemes trigger numerous accidents such as gas explosions and coal and gas outbursts. Many scholars performed numerous studies and explored some methods such as hydraulic fracturing for enhancing the permeability in coal seams [14-16]. Hydraulic fracturing refers to drilling boreholes in the coal seams, followed by generating fractures through highpressure water as a medium. In these enclosed boreholes, hydraulic pressure is utilized to overcome the tensile strength of surrounding rocks [17]. After hydraulic fracturing, the initial fractures are formed in the coal, and numerous secondary fractures are produced [17]. Gas transport channels can be increased while promoting the desorption of adsorbed gas, thereby leading an increase in coal permeability and range $[18,19]$. In recent years, some scholars developed directional hydraulic fracturing and pulsed hydraulic fracturing techniques $[20,21]$.

Moreover, the effective gas control has always remained a technical difficulty in the fully mechanized mining of low- permeability ultrathick coal seams. As described earlier, some scholars have proposed numerous gas control methods and attained favorable results. In the fully mechanized mining of low-permeability ultrathick coal seams, gas has various sources and is significantly challenging to control. Currently, one method addressing the control of multisource gas in the working face is lacking. This study focused on mining the No. 9-15 coal in Liuhuanggou Coal Mine, Xinjiang Province, China, and innovatively proposed a comprehensive gas control method. It is based on the gas emission analysis in which gas predrainage alongside the coal seam, high-position drilling on the top, preburial of pipes in the goaf, and pressure-balancing ventilation are combined. Considering the poor gas predrainage effect for low-permeability coal seams, the permeability and gas predrainage are enhanced by hydraulic fracturing. In this regard, a scheme of hydraulic fracturing is designed, and the performance of the prefracturing and permeability enhancement in the coal seams is verified through field measurements. Lastly, the proposed source-separation comprehensive gas control method's effectiveness and reliability are validated using long-term field tests. The proposed gas control concept and methods can provide a valuable reference for other similar projects.

\section{Case Study}

2.1. Mining and Geological Conditions. As shown in Figure 1, the No. 9-15 coal seam, with a mean thickness of $32.94 \mathrm{~m}$ and a mean inclination angle of $24^{\circ}$, is the primary mineable coal seams in Liuhuanggou Coal Mine. The coal seam has excellent hardness and undeveloped fractures. Also, the measured gas content and gas pressure in the No. 9-15 coal seam were $3.85 \mathrm{~m}^{3} / \mathrm{t}$ and $0.5 \mathrm{MPa}$, respectively. Besides, the permeability coefficient ranged from 0.011814 to $0.061668 \mathrm{~m}^{2} / \mathrm{MPa}^{2} \mathrm{~d}$, and the attenuation coefficient of gas flow was $1.03-1.28 \mathrm{~d}^{-1}$ in the borehole, suggesting a low-permeability coal seam.

No. 7 and No. 4-5 coal seams were also located above the No. 9-15 coal seam with mean thicknesses of $2.31 \mathrm{~m}$ and $7.18 \mathrm{~m}$, respectively. Specifically, the No. 7 coal seam was unrecoverable. The gas content in No. 7 and No. 4-5 coal seams was $4.14 \mathrm{~m}^{3} / \mathrm{t}$ and $3.5 \mathrm{~m}^{3} / \mathrm{t}$, respectively. The distance between No. 4-5 and No. 7 coal seams was $1.85 \mathrm{~m}$, while the distance between No. 7 and No. 9-15 coal seams was $20.95 \mathrm{~m}$. As illustrated in Figure 2, the roof strata of the No. 9-15 coal seam are mainly composed of siltstones and mudstones.

As an operating background in this study, the No. (915)06 panel was selected, $60 \mathrm{~m}$ away from the No (9-15)04 goaf. North of the (9-15)06 panel is the area of unmined coal. The No. (4-5)04 goaf is located on the inclined top of the north part, and the No. (4-5)02 goaf is right above the No. (9-15)06 panel. The tailgate in the No. (9-15)06 panel is inside staggered the tailgate in the No. (4-5)02 panel with a distance of $23 \mathrm{~m}$, while the headgate in the No. (9-15)06 panel is inside staggered the headgate in the No. (4-5)02 panel with a distance of $11 \mathrm{~m}$. A slicing mining method was used for the No. 9-15 coal seam. In the No. (9-15)06 panel, a fully mechanized longwall caving method was used to 


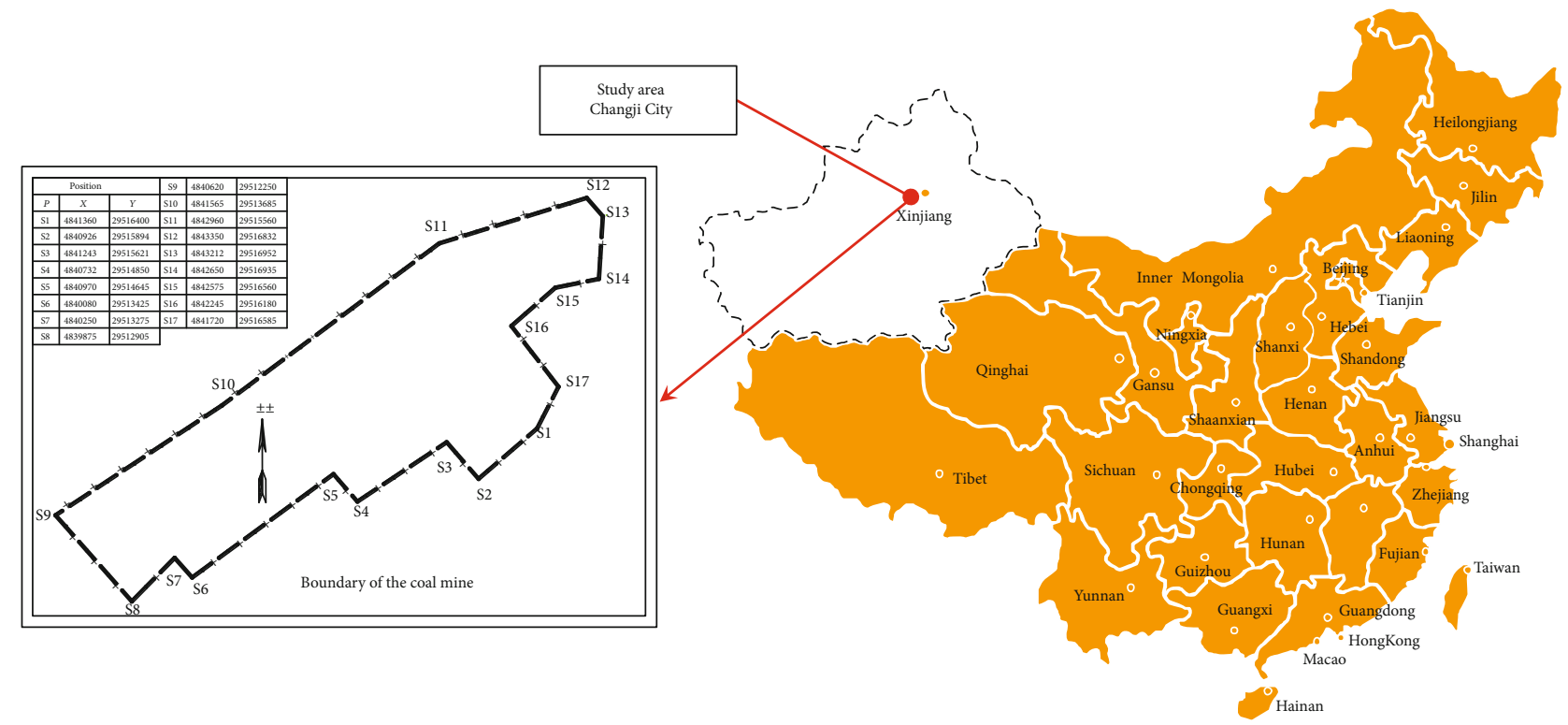

Figure 1: Locational map of Liuhuanggou Coal Mine, China.

top-slicing the No. 9-15 coal, with a mining height of $9 \mathrm{~m}$ and a mechanized mining height of $3 \mathrm{~m}$. The strike length and inclined length of the working face were $1045 \mathrm{~m}$ and $100 \mathrm{~m}$, respectively.

2.2. Coal Seam Mechanical Parameters. To measure the related mechanical parameters of the No. 9-15 coal seam, the No. 9-15 coal samples were collected from the tailgate. Because of the significant sample thickness, coal samples were sliced into three layers: the upper, middle, and lower slices. Coal samples were processed into standard cylindrical specimens with different sizes (e.g., $\Phi 50 \mathrm{~mm} \times 100 \mathrm{~mm}$ and $\Phi 50 \mathrm{~mm} \times 25 \mathrm{~mm})$. Then, an MTS815 electrohydraulic servo rock tester was used to perform uniaxial compressive, triaxial compressive, and Brazilian disk splitting tests. The due parameters were then acquired on the standard samples, including uniaxial compressive strength $\left(\sigma_{\mathrm{c}}\right)$, tensile strength $\left(\sigma_{\mathrm{t}}\right)$, elasticity modulus $(E)$, Poisson's ratio $(v)$, cohesive force $(C)$, and internal friction angle $(\varphi)$. Each test was repeated five times, and then the results were averaged. Table 1 lists the mechanical parameters of the No. 9-15 coal seam. The mean uniaxial compressive strength of the No. 9-15 coal was $35.35 \mathrm{MPa}$, suggesting excellent coal seam hardness. Owing to poor permeability, gas predrainage performance on the coal seam was far from ideal. During mining in the No. (9-15)06 panel, gas control was crucial.

2.3. In Situ Measurement of Crustal Stress. To gain an indepth knowledge of the crustal stress distribution in the Liuhuanggou Mine, in situ measurements were performed. The accuracy of in situ measurement was related to selected methods and sensors. As the stress relief method, a CSIRO hollow inclusion stress gauge was used to possess numerous advantages, including the accuracy, reasonable distribution of numerous strain gauges, and a wide application range. The measuring points should be selected far from the areas with complex geological structures and significant mining effects on this subject. Figure 3 shows five measuring points of crustal stress selected in this study. Also, in situ stress measurement points of crustal stress and borehole layout parameters are listed in Table 2. Drilling depth ranges from $10 \mathrm{~m}$ to $12.8 \mathrm{~m}$ with dominant lithology between fine sandstone and siltstone. Besides, Figure 4 displays the in situ crustal stress measurement results in Liuhuanggou Mine, in which $\sigma_{H}, \sigma_{h}$, and $\sigma_{V}$ denote the maximum horizontal stress, the minimum horizontal stress, and the principal vertical stress, respectively. The dominant azimuth angle and direction of $\sigma_{H}$ and $\sigma_{h}$ were $230^{\circ}$ and $140^{\circ}$, respectively. Figure 4 shows the crustal stress direction at each measuring point.

Moreover, Figure 5 illustrates the stress field in Liuhuanggou Mine that $\sigma_{\mathrm{V}}>\sigma_{\mathrm{H}}>\sigma_{\mathrm{h}}$. As shown in Figure 5, vertical stress dominates the crustal stress field, and various principal stresses increase with increasing burial depth. As a result, vertical stress was slightly smaller than the weight of the overlying strata per unit area. Based on the method of least squares regression $\left(R^{2}\right)$, the following equations were written between various main principal stresses and burial depth $(h)$.

$$
\left\{\begin{array}{l}
h=16.7 \sigma_{V}+244, R^{2}=0.60 \\
h=13.0 \sigma_{V}+302, R^{2}=0.50 \\
h=18.3 \sigma_{V}+304, R^{2}=0.74
\end{array}\right.
$$

2.4. Analysis of Gas Sources in the No. (9-15)06 Panel. Many scholars believe that gas emission sources in the working face mining are coal walls, fallen coal, goaf, and neighboring coal seams [22]. Four main gas emission sources were identified in the No. (9-15)06 working face by analyzing the arrangement and surrounding mining conditions. 


\begin{tabular}{|c|c|c|c|c|c|}
\hline No. & Lithology & Column & $\begin{array}{c}\text { Thickness } \\
\text { (m) }\end{array}$ & $\begin{array}{l}\text { Depth } \\
\text { (m) }\end{array}$ & Remark \\
\hline 1 & Siltstone & 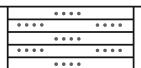 & 17.39 & 343.52 & \\
\hline 2 & Fine sandstone & $\ldots$ & 2.89 & 346.41 & \\
\hline 3 & Carbonaceous mudstone & \begin{tabular}{llll|} 
& $\cdots . .$. & $\cdots$ \\
\end{tabular} & 1.35 & 347.76 & \\
\hline 4 & 4-5 coal seam & & 7.18 & 354.94 & Coal \\
\hline 5 & Siltstone & & 1.85 & 356.79 & \\
\hline 6 & 7 coal seam & & 2.31 & 359.10 & Coal \\
\hline 7 & Mudstone & & 3.65 & 362.75 & \\
\hline 8 & Carbonaceous mudstone & 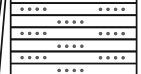 & 2.23 & 364.98 & \\
\hline 9 & Fine sandstone & & 1.30 & 366.28 & \\
\hline 10 & Siltstone & & 11.46 & 377.74 & \\
\hline 11 & 9-12 coal seam & & 13.51 & 391.25 & Coal \\
\hline 12 & Mudstone & & 0.90 & 392.15 & \\
\hline 13 & $13-15$ coal seam & & 19.43 & 411.58 & Coal \\
\hline 14 & Carbonaceous mudstone & & 5.76 & 417.34 & \\
\hline 15 & Siltstone & \begin{tabular}{|llll}
$\cdots$ & $\ldots$ & $\ldots$ \\
$\cdots$ & $\ldots .$. & \\
& $\cdots$ & \\
\end{tabular} & 5.11 & 422.45 & \\
\hline 16 & Fine sandstone & \begin{tabular}{|l}
$\ldots \ldots$ \\
$\ldots \ldots$ \\
$\ldots \ldots$ \\
$\ldots$
\end{tabular} & 9.17 & 431.62 & \\
\hline
\end{tabular}

Figure 2: Stratigraphy column of test site from Liuhuanggou Coal Mine, China.

TABLE 1: Mechanical properties of the No. 9-15 coal.

\begin{tabular}{lcccccc}
\hline Lithology & $\begin{array}{c}\sigma_{\mathrm{c}} \\
(\mathrm{MPa})\end{array}$ & $\begin{array}{c}\sigma_{\mathrm{t}} \\
(\mathrm{MPa})\end{array}$ & $\begin{array}{c}E \\
(\mathrm{GPa})\end{array}$ & $v$ & $\begin{array}{c}C \\
(\mathrm{MPa})\end{array}$ & $\begin{array}{c}\varphi \\
\left({ }^{\circ}\right)\end{array}$ \\
\hline 9-15 coal upper & 39.06 & 1.96 & 3.84 & 0.26 & 3.8 & 40 \\
9-15 coal middle & 35.44 & 2.04 & 3.79 & 0.21 & 4.4 & 41 \\
9-15 coal lower & 31.56 & 1.91 & 2.32 & 0.23 & 3.9 & 42 \\
Average & 35.35 & 1.97 & 3.29 & 0.23 & 4.03 & 41 \\
\hline
\end{tabular}

2.4.1. Gas Emission Quantity from Coal Walls $\left(Q_{1}\right)$. When the working face was to be moved forward, fresh coal walls were exposed to the air. Then, the pressure balance was broken after reliving the rock pressure. Due to a gas pressure gradient in the coal, gas was emitted through coal fractures towards the working face.

2.4.2. Gas Emission Quantity from Top Coal Caving $\left(Q_{2}\right)$. Before caving the top coal in the working face, the top coal was first fully broken under supporting pressure. The original gas pressure balance in the coal seam was then broken during the crushing of the top coal. Hence, the adsorbed gas in the coal seam was converted into a stable state of free gas and then emitted into the working face during top coal caving.

2.4.3. Gas Emission Quantity from the Goaf $\left(Q_{3}\right)$. Using the fully mechanized caving method, the recovery ratio in the No. (9-15)06 panel was about $85 \%$, and a significant amount of coal would be left in the goaf. Therefore, gas from the unmined coal was the main source of the emitted gas in the goaf. Also, the top layer mining in the No. 9-15 coal seam affected the bottom coal seam mining by generating numerous fractures and emitting a significant amount of gas.

2.4.4. Gas Emission Quantity from the Neighboring Coal Seams $\left(Q_{4}\right)$. As shown in Figure 2, the No. 7 and No. 4-5 coal seams locate right above the No. 9-15 coal with a distance of $20.95 \mathrm{~m}$ and $22.8 \mathrm{~m}$, respectively, and include a high content of gas. After mining the No. (9-15)06 panel, the No. 7 and No. 4-5 coal seams were located in the roof caving zone, in 


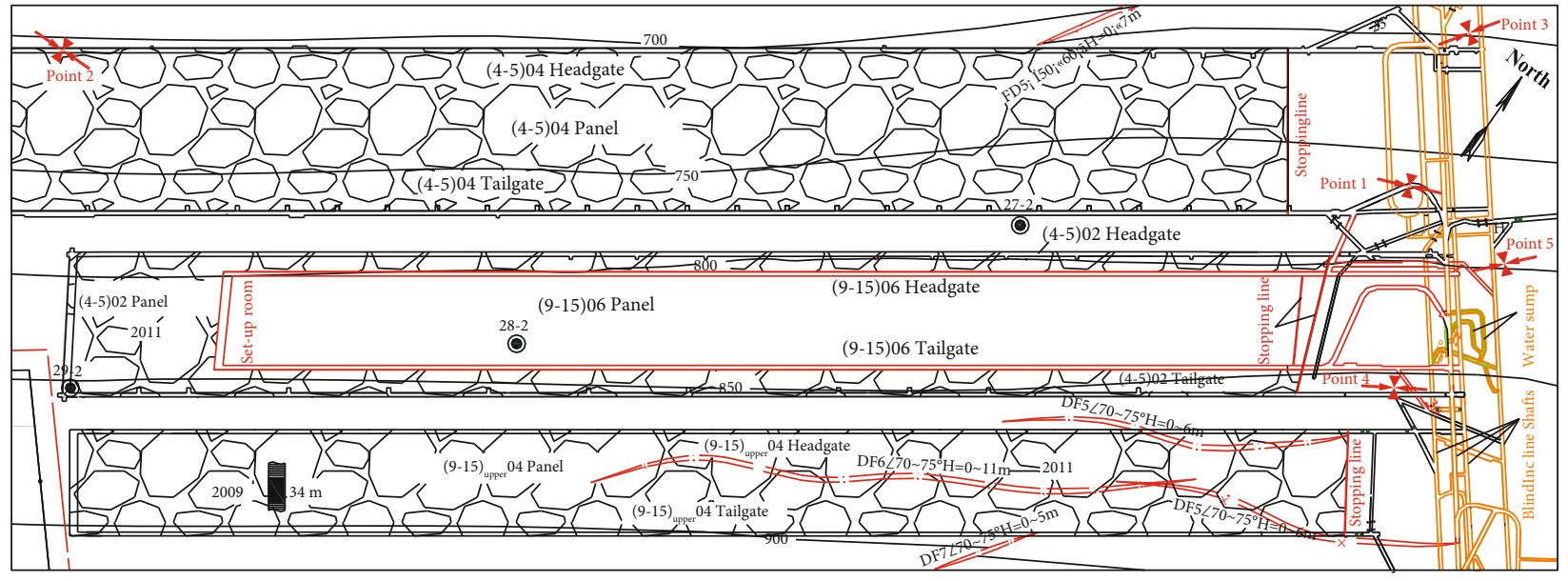

Figure 3: Layout of the No. (9-15)06 panel from Liuhuanggou Coal Mine, China.

TABLE 2: In situ stress measurement points and borehole layout parameters.

\begin{tabular}{|c|c|c|c|c|c|}
\hline No. & $\begin{array}{c}\text { Drilling } \\
\text { depth }(\mathrm{m})\end{array}$ & Azimuth $\left({ }^{\circ}\right)$ & $\begin{array}{c}\text { Elevation } \\
\text { angle }\left({ }^{\circ}\right)\end{array}$ & Depth (m) & Lithology \\
\hline I & 12.8 & 331 & 5 & 346 & $\begin{array}{c}\text { Fine } \\
\text { sandstone }\end{array}$ \\
\hline II & 12.0 & 325 & 10 & 482 & $\begin{array}{c}\text { Fine } \\
\text { sandstone }\end{array}$ \\
\hline III & 10.0 & 328 & 5 & 448 & $\begin{array}{c}\text { Fine } \\
\text { sandstone }\end{array}$ \\
\hline IV & 10.5 & 320 & 41 & 360 & Siltstone \\
\hline V & 10.6 & 50 & 41 & 405 & Siltstone \\
\hline
\end{tabular}

which a connection was made between the No. (9-15)06 panel and the No. (4-5)02 goaf. Besides, the gas emitted from the No. 7 and No. 4-5 coal seams was accumulated in the overlying strata of the goaf in the No. (9-15)06 panel.

To conclude, the total gas emission $(Q)$ from the No. (9-15)06 panel equals the sum of the gas emission from the above sources, i.e., $Q=Q_{1}+Q_{2}+Q_{3}+Q_{4} \cdot Q_{1}$ and $Q_{2}$ can be lowered by gas predrainage alongside the coal seams [23]. The gas from latter two sources accumulated in fractures in the overlying goaf strata. As a result of this accumulation, the friction in fractures of overlying strata quickly triggers a gas explosion in the goaf and threatens the production safety in the working face. Therefore, effective measures are required for drainage or dilution for the gas accumulated on the top of the goaf (i.e., $Q_{3}+Q_{4}$ ).

\section{Increasing the Permeability of Coal Seam by Hydraulic Fracturing}

From the No. 9-15 coal seam, the performance of gas predrainage was weak due to high strength and poor permeability. Therefore, prefracturing was first performed on the coal seam to enhance the permeability by hydraulic fracturing and improve the coal seam's gas predrainage effect.
3.1. Crack Initiation Pressure. Crack initiation pressure refers to the maximum water pressure during hydraulic fracturing. Numerous factors affect the initiation pressure, including burial depth of the coal seam, crustal stress, coal mechanical properties, and original cracks. According to the hydraulic fracturing theory [14, 24-26], tensile cracks dominate the hydraulic fracturing process. Under the action of water pressure in the boreholes and the crustal stress field, when the tensile stress on the tip of the cracks exceeds the tensile strength $\sigma_{\mathrm{t}}$, cracks develop gradually. The initiation pressure $P_{k 1}$ can be estimated (Equation (2)) by ignoring the water seepage effect from the boreholes on the surrounding media [26]:

$$
P_{k 1} \geq 3 \sigma_{3}-\sigma_{1}+\sigma_{t}
$$

where $\sigma_{1}$ and $\sigma_{3}$ denote the maximum and minimum principal stresses, respectively, and $\sigma_{t}$ denotes the coal tensile strength.

Besides, gas pressure significantly affects crack initiation and propagation under hydraulic fracturing [27]. Based on statistics from a large number of coal mines in China, $\mathrm{Li}$ et al. carried out a regression analysis and determined the following relationship between crack initiation pressure $P_{k 2}$, burial depth of the coal seam $H$, and gas pressure $P_{0}$ [19]:

$$
P_{k 2}=0.023 H+1.293 P_{0}+2.04 \text {. }
$$

According to the minimum pressure principle, the minimum value between $P_{k 1}$ and $P_{k 2}$ was selected as the initiation pressure of the coal seam $\left(P_{k}\right)$ :

$$
P_{k}=\min \left\{P_{k 1}, P_{k 2}\right\} \text {. }
$$

In this study, the mean burial depth of the working face was approximately $420 \mathrm{~m}$, the mean unit weight of the overlying strata was $23 \mathrm{kN} / \mathrm{m}^{3}$, and the gas pressure of the coal seam was $0.5 \mathrm{MPa}$. Also, the maximum and minimum principal stresses in the study area were 10.54 MPa and 6.34 MPa, respectively. From Table 1, the 


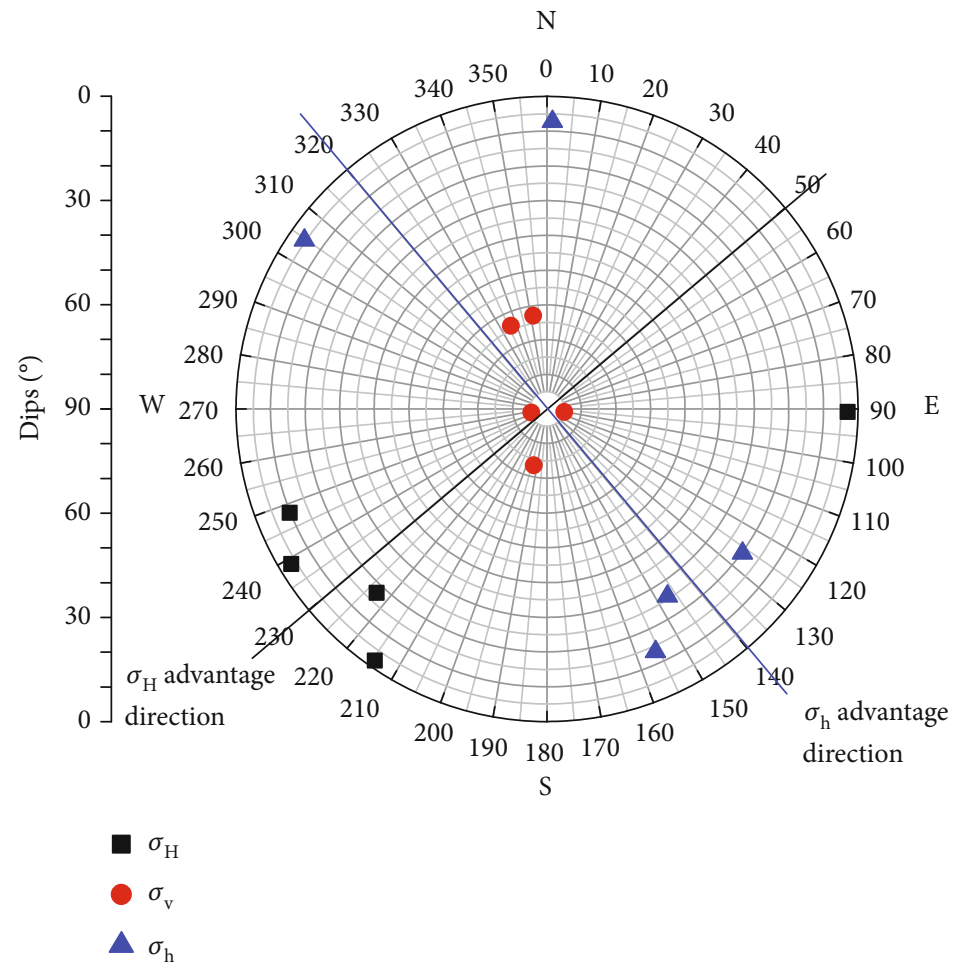

Figure 4: In situ stress directions of Liuhuanggou Coal Mine.

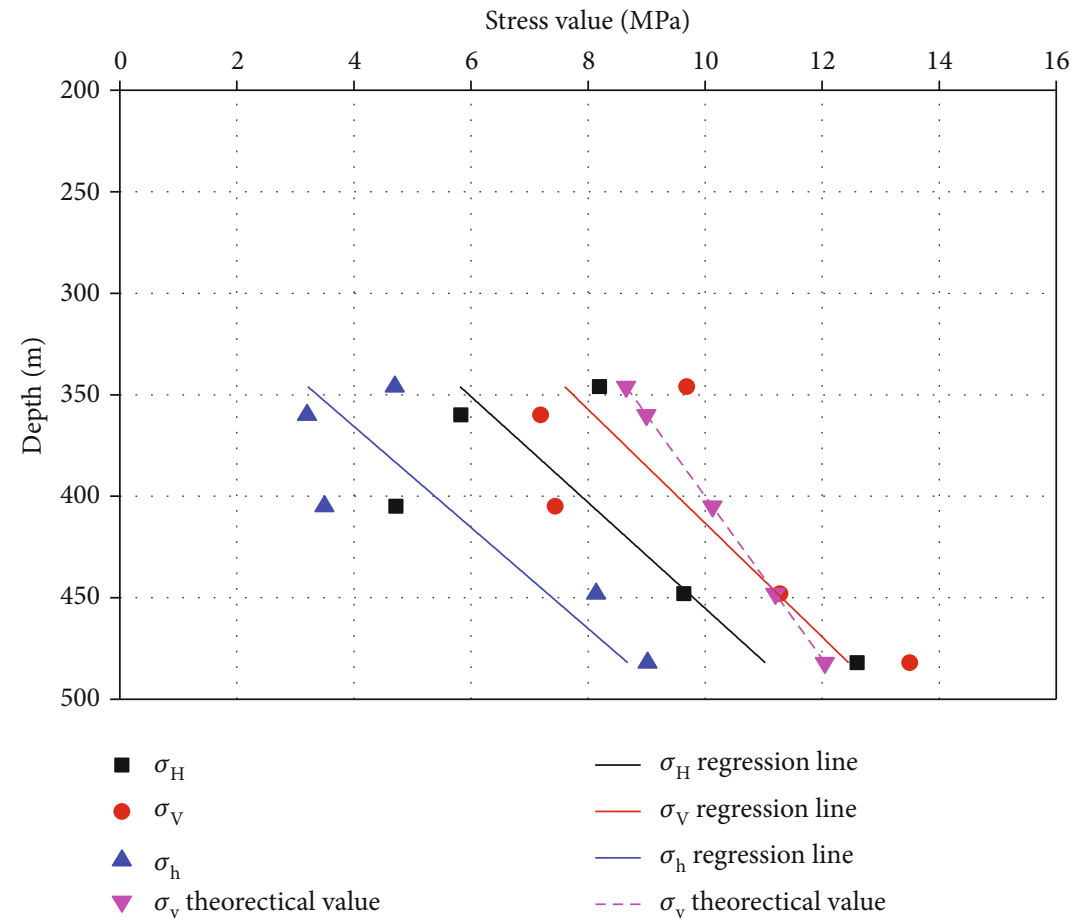

Figure 5: In situ stress magnitude (MPa) vs. depth (m) of Liuhuanggou Coal Mine. 


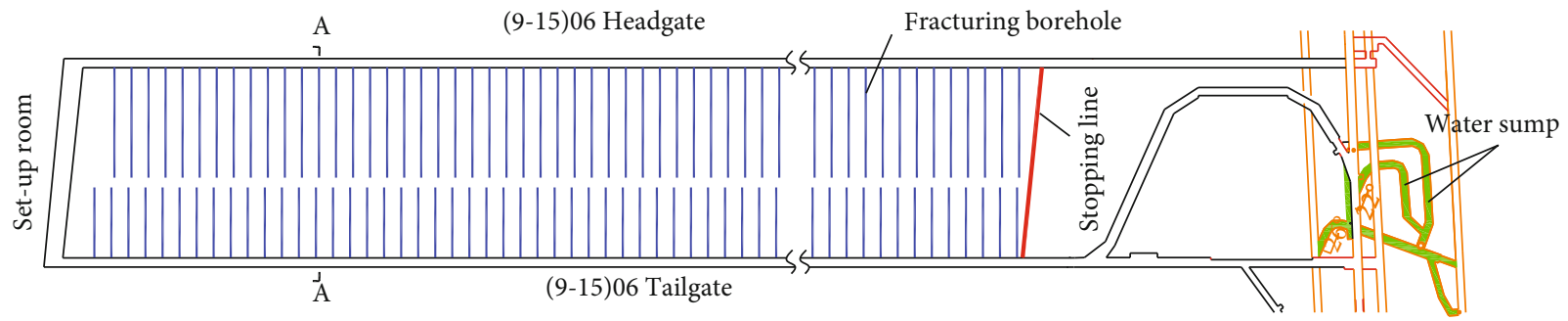

(a)

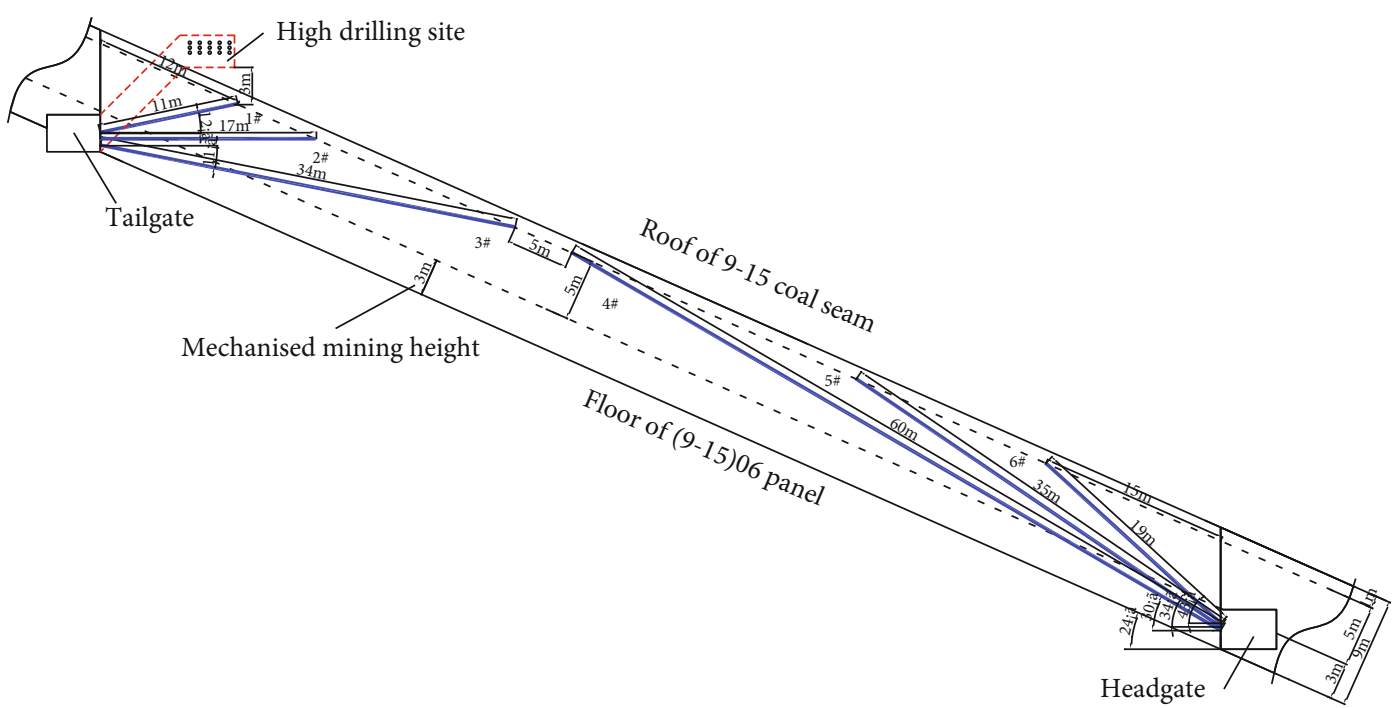

(b)

Figure 6: Layout of hydraulic fracturing borehole. (a) Plane of hydraulic fracturing borehole. (b) Profile of hydraulic fracturing borehole.

average tensile strength of the No. 9-15 coal was $1.97 \mathrm{MPa}$. $P_{k 1}$ and $P_{k 2}$ equal $10.45 \mathrm{MPa}$ and $10.74 \mathrm{MPa}$, respectively. Therefore, $P_{k}$ is $10.45 \mathrm{MPa}$.

\subsection{Enhancing Coal Seam Permeability by Hydraulic Fracturing}

3.2.1. Arrangement of Hydraulic Fracturing Boreholes. The spatial positions of the hydraulic fracturing and highposition gas drainage in boreholes on the roof of the working face were analyzed to avoid damages to gas drainage boreholes. This analysis was based on geological and engineering conditions of the No. (9-15)06 panel and coal seam characteristics. Figure 6 shows an arrangement of the hydraulic fracturing in boreholes. A set of boreholes with a diameter of $75 \mathrm{~mm}$ were arranged on the inner sides of the tailgate and headgate. The first group of boreholes was arranged $15 \mathrm{~m}$ from the set-up room of the No. (9-15)06 panel, and the interval between every two groups of boreholes is $8 \mathrm{~m}$. Table 3 lists the detailed parameters of boreholes.

3.2.2. Main Equipment. Many field equipment sets are used for hydraulic fracturing, including a high-pressure water injection pump, water tank, flow controller, pressure gauge, and high-pressure water pipe. The maximum pressure of the water injection pump was $35 \mathrm{MPa}$, and the water flow velocity was $200 \mathrm{~L} / \mathrm{min}$.
TABLE 3: Detailed borehole parameters.

\begin{tabular}{lccccc}
\hline Location & Number & $\begin{array}{c}\text { Dip } \\
\text { angle, }\end{array}$ & $\begin{array}{c}\text { Diameter, } \\
\text { mm }\end{array}$ & Length, $\mathrm{m}$ & $\begin{array}{c}\text { Height of } \\
\text { the orifice } \\
\text { from the } \\
\text { floor of } \\
\text { roadway, m }\end{array}$ \\
\hline \multirow{3}{*}{ Tailgate } & 1 & 12 & 75 & 11 & 1.5 \\
& 2 & 0 & 75 & 17 & 1.0 \\
Headgate & 5 & -11 & 75 & 34 & 0.5 \\
& 5 & 30 & 75 & 60 & 1.5 \\
& 6 & 34 & 75 & 35 & 1.8 \\
\end{tabular}

3.2.3. Sealing of Boreholes. Borehole sealing is a critical makeor-break step that determines the effectiveness of hydraulic fracturing. At present, cement and other particular hole packers were used for sealing [19]. The latter was used in the present field test. Under high-pressure water, the rubber gasket was compressed, then expanded radially in the hole packer, and reached the inner wall of the hole to achieve a seal. The use of this method provided a high sealing efficiency with a simple operating process in boreholes. However, this process sets high requirements on the boreholes, such as the high construction quality and the smooth borehole wall. 


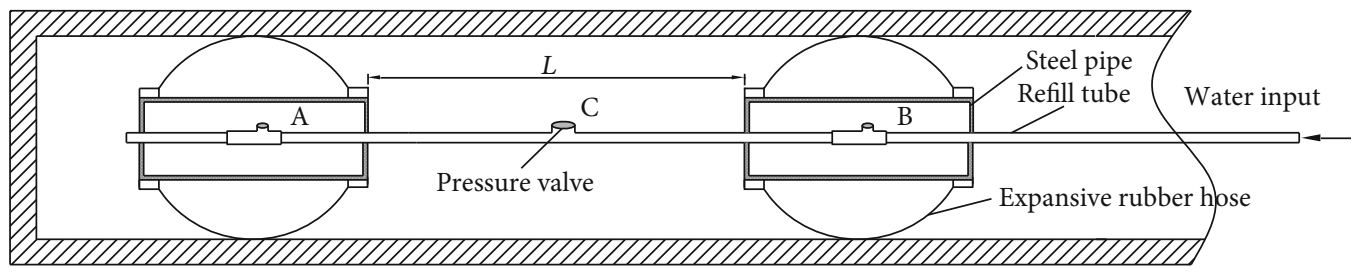

FIGURE 7: A schematic diagram of sectional sealing in low-permeability coal seams.
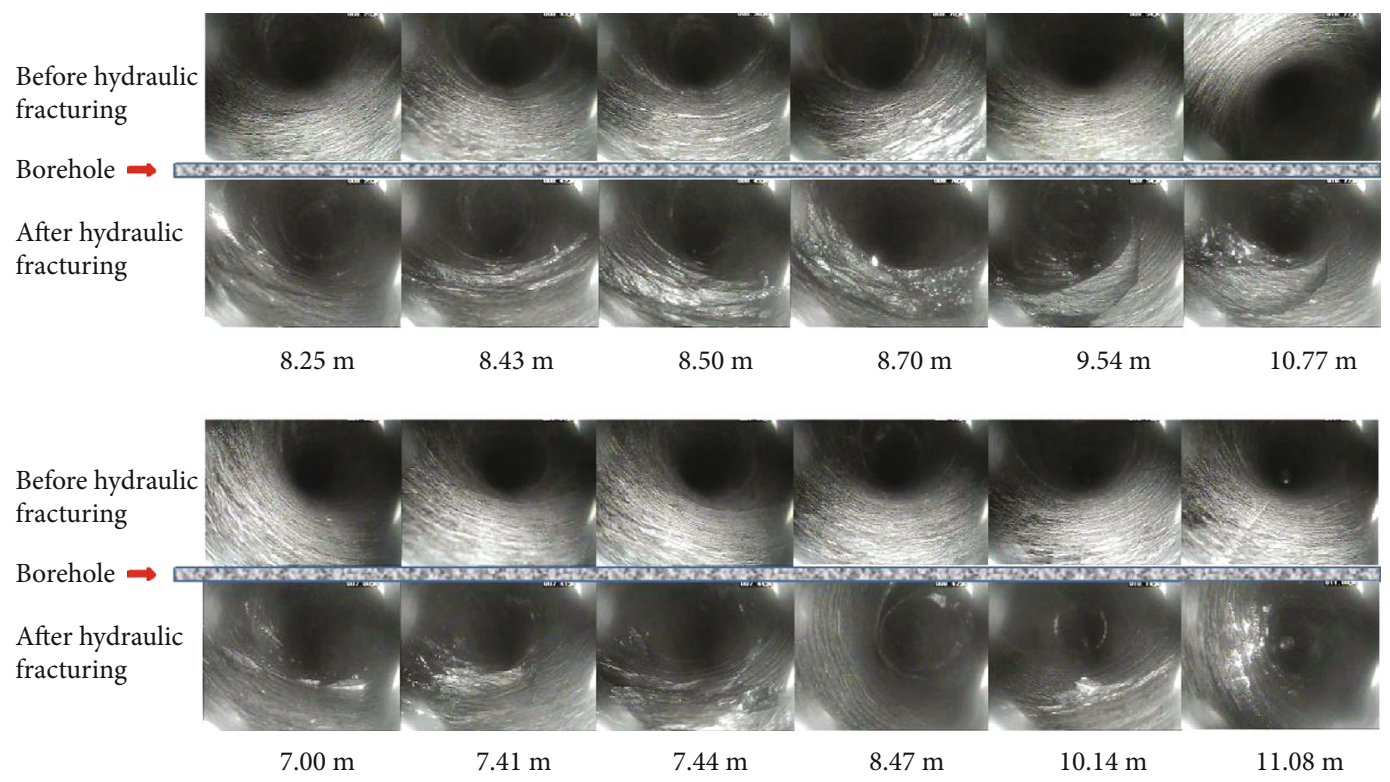

FIgURE 8: Fracture distribution contrast of part boreholes before and after hydraulic fracturing.

3.2.4. Fracturing Technology. Spatial propagation of hydraulic fractures directly affects the permeability enhancement of coal seams. The hydraulic fractures are always propagated parallel to the maximum principal stress and perpendicular to the minimum principal stress [17, 28-30].

According to in situ measurement results, the vertical stress was dominated the crustal stress in Liuhuanggou Mine. The dominant angle of the minimum horizontal stress was $140^{\circ}$. The angle between the dominant direction of the minimum horizontal stress and the gate axis of the panel was about $84^{\circ}$. Hydraulic fractures are most likely to propagate radially from the borehole; therefore, a backwardsegmented fracturing technology was adopted to enhance hydraulic fracturing performance. Figure 7 illustrates the present borehole sealing method. Two-hole packers were connected in series, and the spacing distance between them (denoted as $L$ ) was the sectional fracturing length. In this study, $L$ equals $8-10 \mathrm{~m}$. As shown in Figure 7 , the initiation pressure of valve in hole packer A equals in hole sealer B, and both are smaller than the initiation pressure of valve C. Thus, the fracturing and sealing of local borehole can be achieved.

3.3. Verification of Permeability Enhancement of the Coal Seam via Hydraulic Fracturing. To evaluate the enhancement of permeability in the coal seam by the hydraulic fracturing, the following two methods were used for the accuracy: borescope examination and borehole gas emission quantity measurement.

3.3.1. Borescope Examination. A stratum detector was employed for examining fracturing results in the borehole before and after the hydraulic fracturing. This study emphasizes both crack initiation and propagation behaviors in the borehole. Figure 8 shows the distribution of cracks in the borehole before and after the hydraulic fracturing. The inner wall of the initial borehole was complete in shape, while few original cracks were found in the borehole. After the hydraulic fracturing, cracks were propagated radially or in a spiral pattern from the borehole wall. This result correlates with the distribution of crustal stress in the test region, which was consistent with the predicted results as described above. In conclusion, the coal seam showed satisfactory prefracturing performance.

3.3.2. Measurement of Gas Emission Quantity from the Borehole. Before and after the hydraulic fracturing, gas predrainage flows were monitored using an orifice plate flow meter [31]. The gas flow in the borehole can be calculated as Equations (5) and (6):

$$
\begin{aligned}
Q_{m} & =k b \sqrt{\Delta h} \delta_{p} \delta_{T}, \\
Q_{c} & =Q_{m} X
\end{aligned}
$$




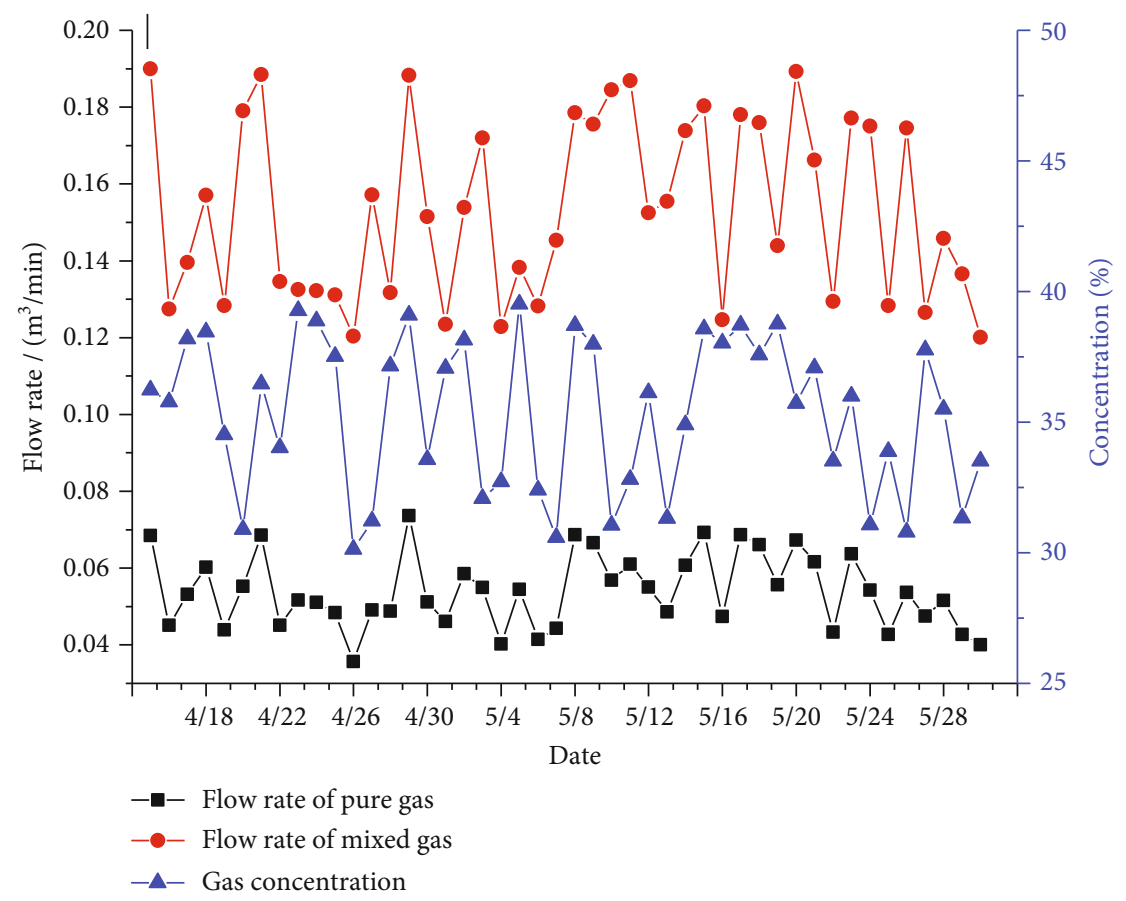

(a)

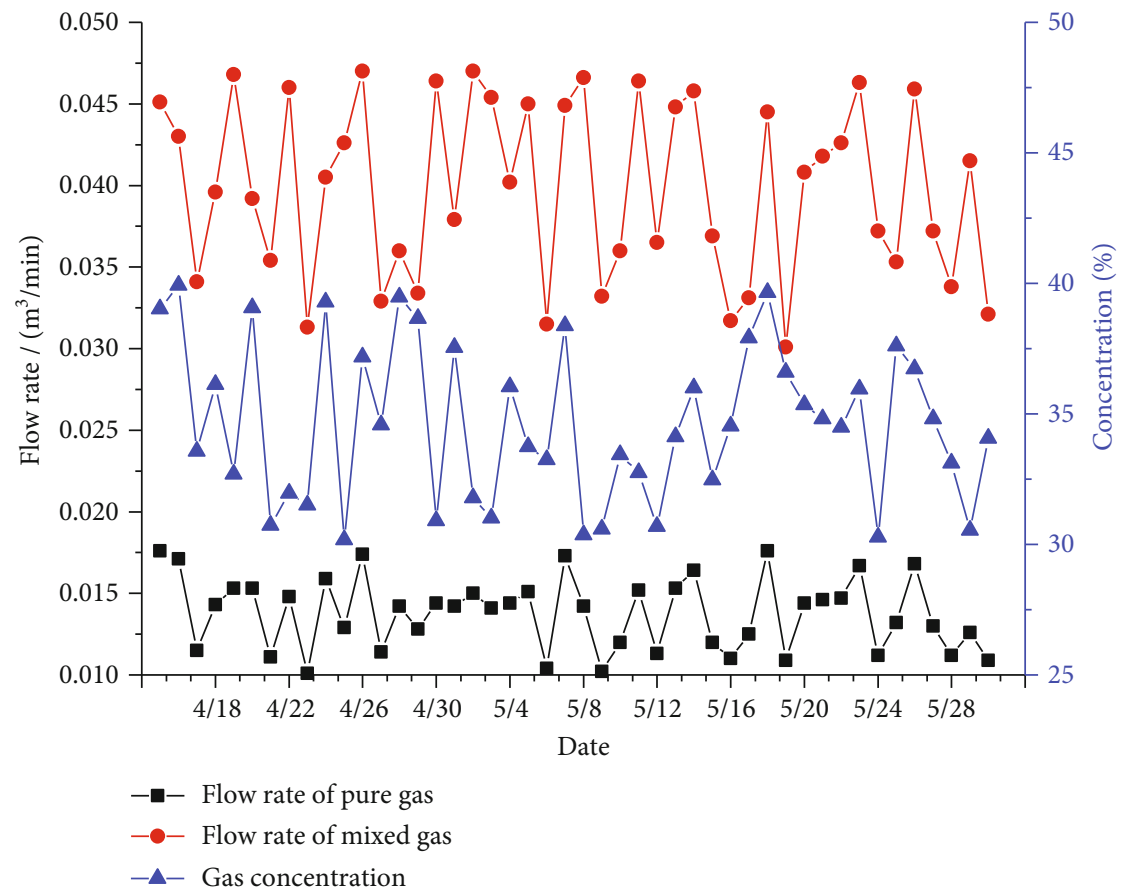

(b)

Figure 9: Variation of predrainage gas volume of single-hole with time. (a) Borehole after hydraulic fracturing. (b) Original borehole.

where $Q_{m}$ and $Q_{c}$ denote the flow of drained gas mixture and pure gas, respectively, in $\mathrm{m}^{3} / \mathrm{min}$. $X$ denotes gas concentration (\%) in the gas mixture, and $k$ is the actual characteristic coefficient of orifice flow. $b$ is the correction coefficient of gas concentration $(b=\sqrt{1 /(1-0.00446 X)})$, and $\Delta h$ is the difference between the measured pressure
$\left(\mathrm{mmH}_{2} \mathrm{O}\right)$ of the front and rear ends in the hole plate. $\delta_{p}$ denotes the correction coefficient of gas pressure $\left(\delta_{p}=\sqrt{P_{T} / 760}\right) .760$ is the standard atmospheric pressure. $P_{T}$ denotes the measured absolute pressure $(\mathrm{mmHg})$ at the windward end of the hole plate. $\delta_{T}$ denotes the correction coefficient of temperature $\left(\delta_{T}=\sqrt{293 /(273+t)}\right) .293$ is 


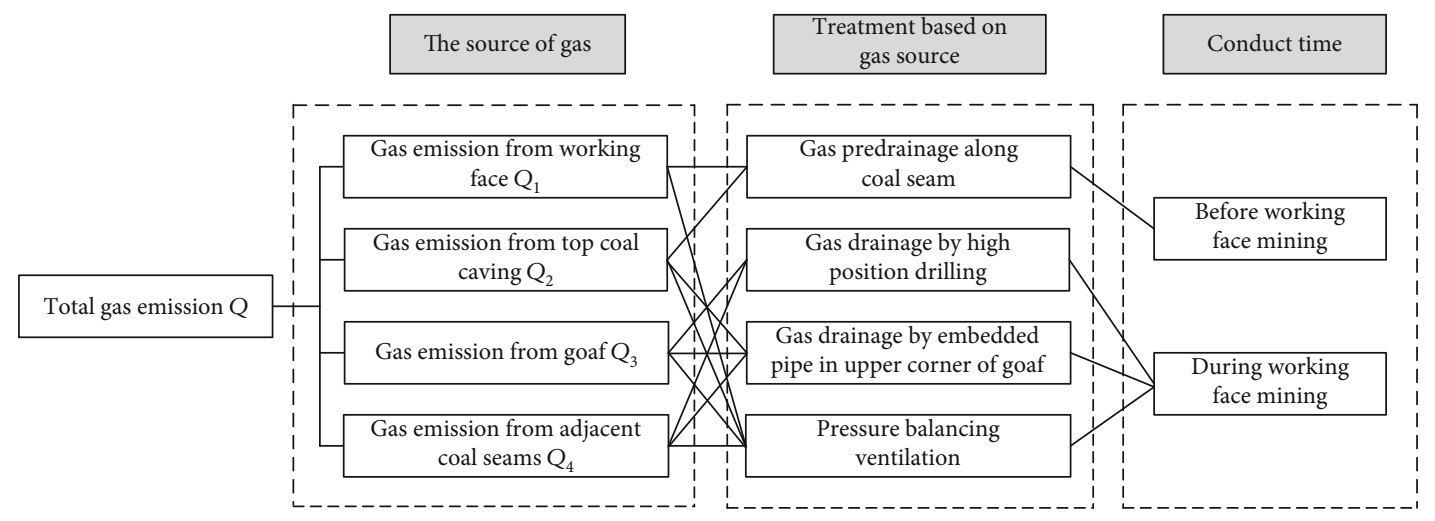

FIGURE 10: Comprehensive control method based on gas sources.

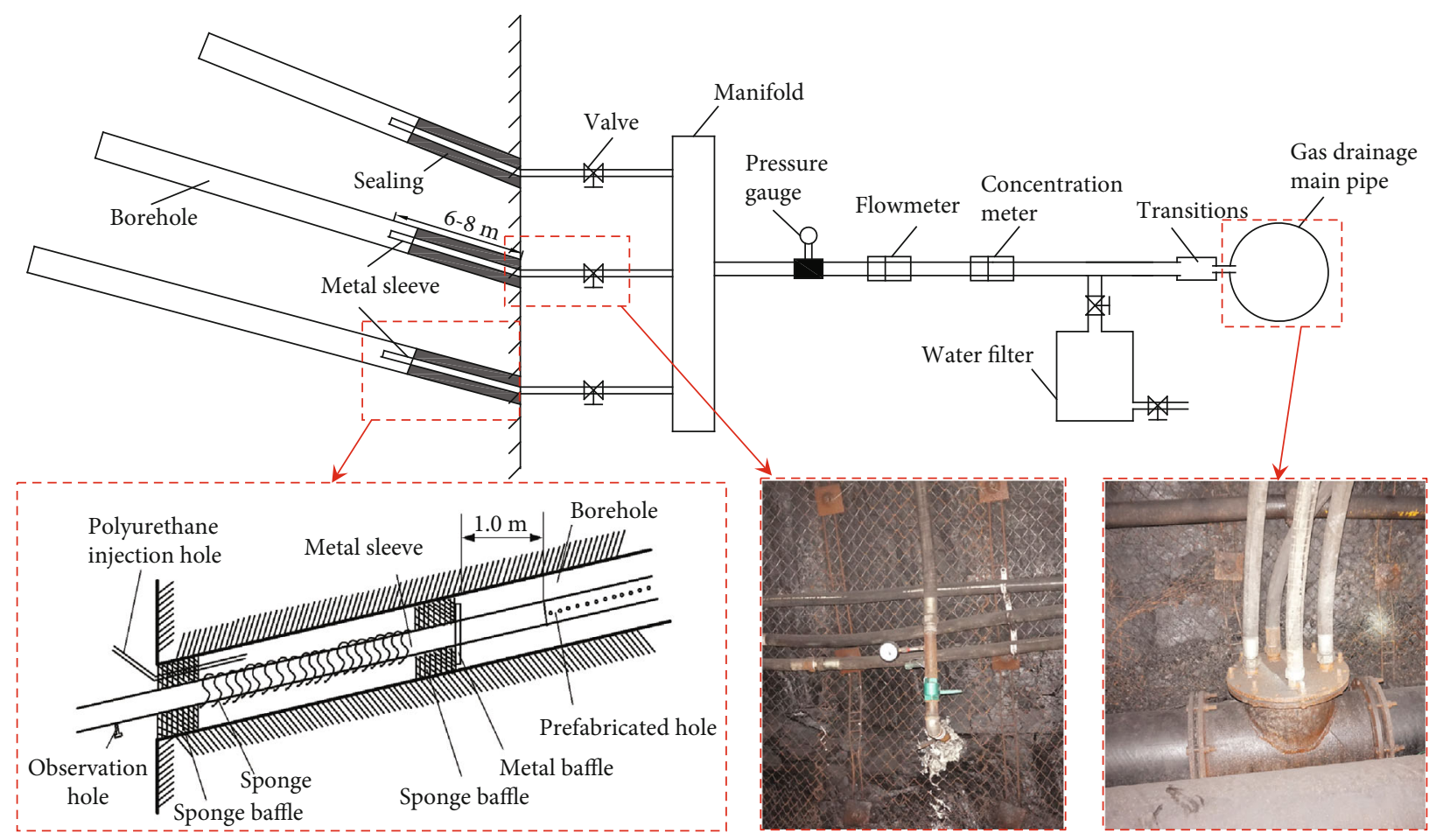

FIGURE 11: Scheme of gas predrainage in the low-permeability coal seam.

the standard absolute temperature $\left({ }^{\circ} \mathrm{C}\right)$. Also, $t$ denotes the temperature $\left({ }^{\circ} \mathrm{C}\right)$ at the measuring point in the gas pipe.

Furthermore, the U-shaped differential pressure gauge readings were obtained and substituted into Equations (5) and (6) to calculate the exhausted gas mixture and pure gas. Figure 9 presents a plot of the results from the various rules of gas predrainage quality in the borehole before and after the hydraulic fracturing. After implementing hydraulic fracturing, the mean gas predrainage quantity from the borehole was enhanced by nearly four times the original value. Besides, in low-permeability hard coals, fractures were propagated around the borehole after the hydraulic fracturing. Therefore, the permeability of the surrounding coal seams was increased, and the performance of gas predrainage was remarkably improved.

\section{Comprehensive Gas Control Based on Sources}

A comprehensive gas control method was proposed by analyzing four main gas emission sources in the No. (9-15)06 panel (Figure 10). Before mining in the panel, the quantity of $Q_{1}$ and $Q_{2}$ was lowered by performing gas predrainage in the coal seam. During the working face mining, the gas was accumulated in the caving zone. In doing so, the fracture zone $\left(Q_{3}+Q_{4}\right)$ was discharged through high-position boreholes on the roof. Meanwhile, drainage pipes were buried along with the tailgate in the panel to address the gas accumulation in the upper corner. Also, pressure-balancing ventilation was implemented during the working face mining. To prevent the air leakage and gas emission in the goaf, the 


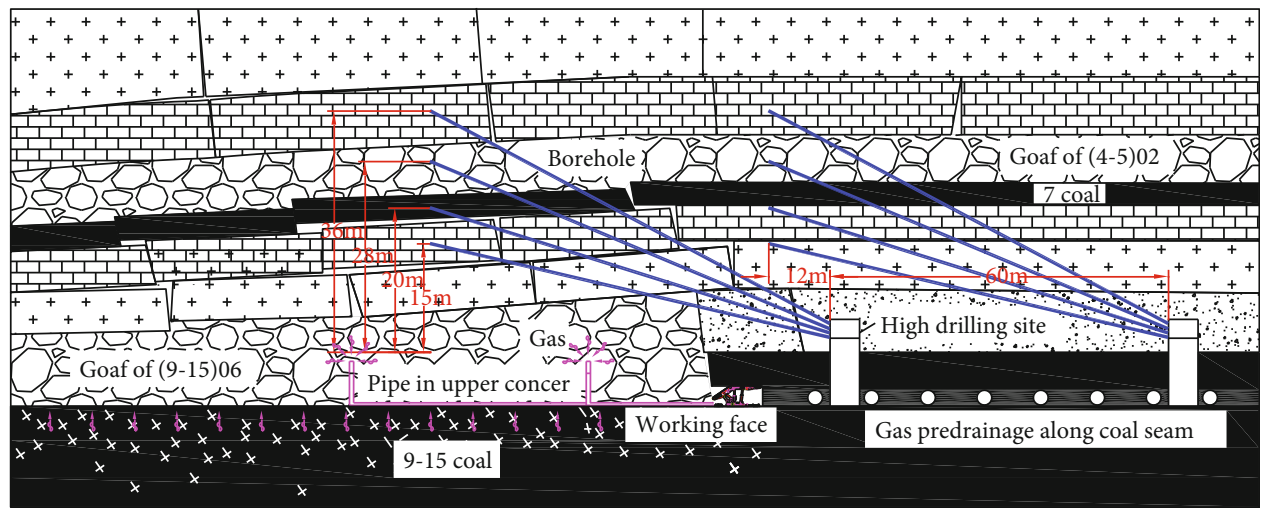

(a)

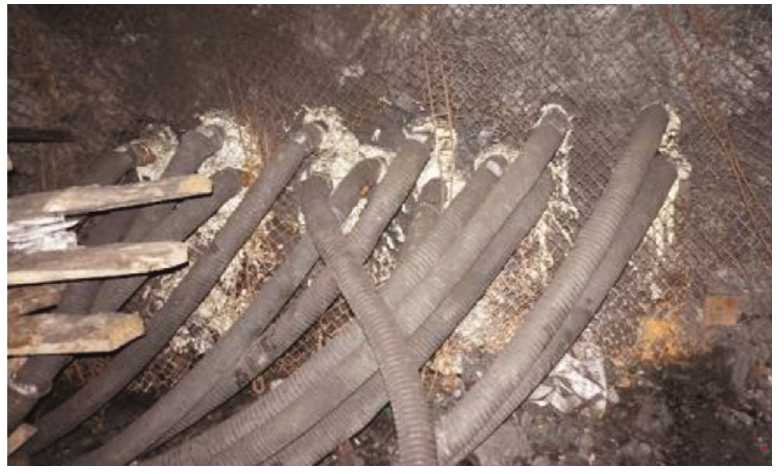

(b)

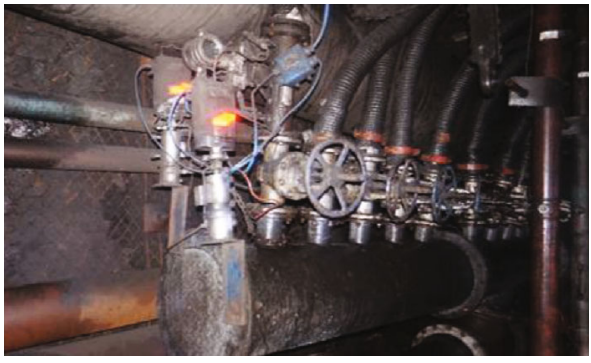

(c)

FIGURE 12: Gas drainage in roof caving and fissure zones of the No. (9-15)06 panel. (a) Overburden structure of (9-15)06 panel and roof highlevel gas drainage boreholes. (b) Boreholes in high drilling site. (c) Metering installation of gas drainage.

difference between the measured pressures of two gate roads was reduced by adjusting the ventilation parameters.

4.1. Gas Predrainage in the Coal Seam. Hydraulic fractured boreholes were also used as gas predrainage holes before the working face mining for the gas predrainage in the coal seam (Figure 11). Accordingly, two purposes were obtained by predrainage holes: the enhancement of gas predrainage and reduction of construction volume.

The system of gas predrainage in the coal seam mainly consists of drainage pipe, filter pipe, collecting pipe, and hole-sealing materials (Figure 11). The auxiliary devices include the flow meter, the concentration meter, and the pressure gauges. Also, metal sleeves with a diameter of $40 \mathrm{~mm}$ and a wall thickness of $3 \mathrm{~mm}$ were put in each fractured borehole, and small-diameter holes were arranged at one of the sleeves' ends. Two sections of the sleeves were arranged around each borehole, and each section was 3-4 m in length. After installation of the sleeves, boreholes were sealed using polyurethane (PU). It is important to note that hole-sealing depth should not exceed the burial depth of the gas drainage pipe in the borehole. Lastly, the sleeves were connected with the gas drainage header pipes, providing a negative pressure of $25 \mathrm{kPa}$.

4.2. Drainage of Gas from the Caving Zone via High-Position Boreholes. Gas emitted from pressure relief in the coal seam floor was an essential gas source in the mining panel. After the working face mining, the overlying strata underwent fracturing and formed the bent subsidence zone, the fracture zone, and the caving zone [32-35]. Meanwhile, many layered and vertical fractures were produced $[36,37]$, and gas was accumulated in these regions. The accumulation of emitted gas from No. 4-5 coal, No. 7 coal, and No. 915 coal increased the gas accidents. Therefore, based on gas predrainage in the coal seam before the mining, long-strike holes were drilled in the high-position drilling site on the roof. It was performed for discharging the gas accumulated in the caving and fracture zones during working face mining (Figure 12). The high-position drilling site was located in the tailgate of the No. (9-15)06 panel. Drilling sites were set at an interval of $60 \mathrm{~m}$. In each drilling site, 16 long boreholes in 4 rows were arranged alongside the strike of the coal seam in a fan-shaped distribution.

4.3. Gas Drainage at the Upper Corner of the Panel. The gas produced in pressure relief from the floor can rush into the goaf and enter the upper corner, resulting in an abundance of gas in the corner. To avoid the above problem, gas drainage pipes were buried at the air return corner on the top of the goaf during working face mining (Figure 12).

4.4. Pressure-Balancing Ventilation for Reducing Air Leakage in the Goaf. The air supply is generally increased for diluting the gas concentration in the return airflow for the panels with 


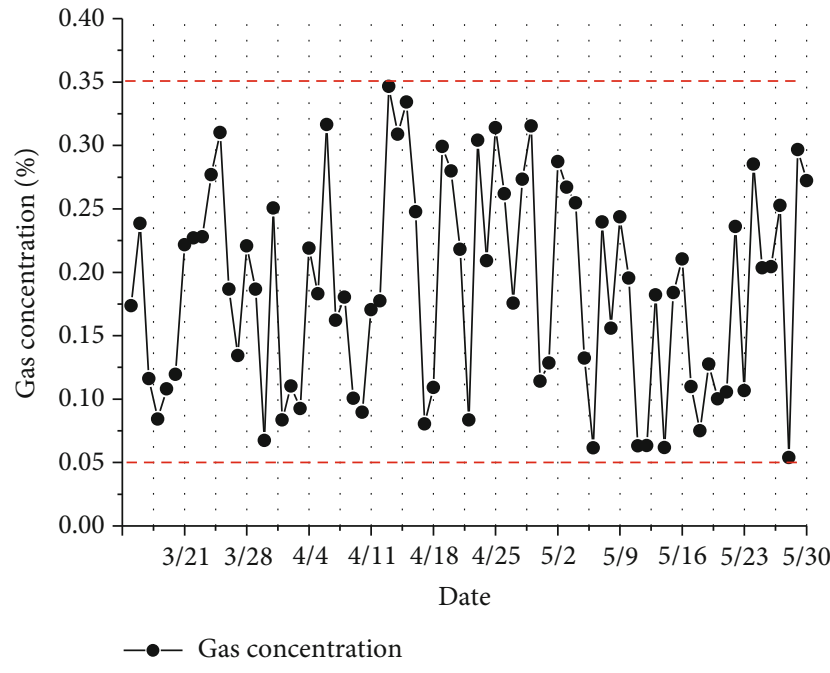

FIGURE 13: Variation law of gas concentration in return air flow of the No. (9-15)06.

U-shaped ventilation. It is an incorrect practice. Increasing the quantity of air supply in the panel blindly can increase the difference in the measured air pressure between the goaf and the panel and air leakage in the panel, leading to an increase in gas emission in the goaf and gas concentration in the panel return airflow [38]. On that basis, pressurebalancing ventilation was adopted to reduce the difference in the measured pressure between two sides in the air intake and return roadways. By the way, the distribution of the ventilation system's pressure was changed [39]. Accordingly, the air leakage can be lowered to inhibit gas emissions from the goaf's upper corner.

4.5. Gas Analysis. A long-term field test was performed in the No. (9-15)06 panel using the comprehensive control method based on the gas sources. Overall, gas was adequately controlled. Figure 13 displays the monitoring of gas concentration in the panel during the working face mining. The gas concentration in the return airflow fluctuated within a range of $0.05 \%$ to $0.35 \%$. The maximum gas concentration was no greater than $0.35 \%$, below the early warning value of $0.5 \%$.

\section{Conclusions}

Gas control has always been a key problem during slice mining of ultrathick coal seams with a high content of gas. This study examined the No. (9-15)06 panel with a mean thickness of $32.94 \mathrm{~m}$ in Liuhuanggou Coal Mine. The No. 9-15 coal seam included low-permeability ultrathick coal seams with a high content of gas. The No. (9-15)06 panel was the top-slicing working face of the No. 9-15 coal, using a fully mechanized top coal caving with a mining height of $9 \mathrm{~m}$. A significant content of gas was emitted from the panel in the working face mining.

Based on the arrangement in the No. (9-15)06 panel and the surrounding mining condition, gas in the panel had four emission sources: from the coal wall, gas top coal caving, the goaf, and the neighboring coal seams. In this study, a comprehensive control method based on gas sources was proposed for the panel. Before the working face mining, gas emissions from the coal walls and top coal caving were lowered via gas predrainage alongside the coal seam. After the working face mining, gas accumulated in the caving and fracturing zones was drained using long-strike boreholes in the high-position drilling site. Drainage pipes were buried in the upper corner of the goaf to avoid gas accumulation emitted from destressed floor coal seams. During the working face mining, pressure-balancing ventilation caused the reduction of air leakage in the goaf and gas emission from the goaf.

Due to the great hardness and poor permeability of the No. 9-15 coal seam, conventional gas predrainage methods were not properly performed on the coal seam. Using hydraulic fracturing caused the enhancement of the permeability in the coal seam. Also, the backward-segmented technology was designed for improving hydraulic fracturing performance. To validate the superiority of the proposed method, the prefracturing performance of the coal seam was evaluated using borescope examination and gas emission test. Field test results demonstrated that the fractures can be developed in the coal seam around the boreholes after hydraulic fracturing. Fractures were mainly initiated radially from the borehole wall and then propagated in a spiral pattern consistent with crustal stress measurements. After the hydraulic fracturing, the mean gas predrainage was enhanced by four times.

Finally, a long-term field test was performed in the No. 9-15 panel to validate the superiority of the proposed comprehensive control method based on the gas sources. Long-term monitoring results indicated that the gas concentration in the return airflow fluctuates within a range of $0.05 \% \sim 0.35 \%$. No warning of excessive gas appeared in the panel. An adequate gas control can effectively ensure mining safety in the panel.

\section{Data Availability}

The data used to support the findings of this study are available from the corresponding authors upon request.

\section{Conflicts of Interest}

The authors declare no conflicts of interest.

\section{Acknowledgments}

This research is supported by the Natural Science Foundation of China (52004144), Natural Science Foundation of Shandong Province, China (ZR2019BEE001, ZR2018MEE009), and Key Research and Development Projects of Shandong Province, China (2019GSF111038). The authors thank the anonymous referees for their careful reading of this paper and valuable suggestions. 


\section{References}

[1] X. L. Yang, G. C. Wen, H. T. Sun et al., "Environmentally friendly techniques for high gas content thick coal seam stimulation-multi-discharge $\mathrm{CO}_{2}$ fracturing system," Journal of Natural Gas Science and Engineering, vol. 61, pp. 71-82, 2019.

[2] T. Q. Xia, F. B. Zhou, J. S. Liu, and F. Gao, "Evaluation of the pre-drained coal seam gas quality," Fuel, vol. 130, pp. 296305, 2014.

[3] F. X. Jiang, L. H. Kong, and C. G. Liu, "Gas emission laws of fully-mechanized sublevel caving mining in extra-thick coal seam," Journal of China Coal Society, vol. 36, no. 3, pp. 407411, 2011.

[4] W. Wang, Y. P. Cheng, H. F. Wang et al., "Fracture failure analysis of hard-thick sandstone roof and its controlling effect on gas emission in underground ultra-thick coal extraction," Engineering Failure Analysis, vol. 54, pp. 150-162, 2015.

[5] Y. P. Fan and Y. B. Wang, "Study on measures to control methane in goaf in mechanized mining extremely thick face of Tashan coal mine," China Safety Science Journal, vol. 26, no. 12 , pp. 116-121, 2016.

[6] H. Guo, C. Todhunter, Q. D. Qu, and Z. Y. Qin, "Longwall horizontal gas drainage through goaf pressure control," International Journal of Coal Geology, vol. 150-151, pp. 276-286, 2015.

[7] Y. Zhang, B. Zhang, L. Li, S. Q. Zhang, J. K. Liu, and J. J. Zhao, "Study on the effect of roof fracture development on gas drainage in steep full-mechanized caving mining," Journal of Mining and Safety Engineering, vol. 31, no. 5, pp. 809-813, 2014.

[8] Z. Q. Liu, "Gas drainage effect analysis of buried pipes in steeply inclined thick coal seam fully-mechanized caving face," Coal Science and Technology, vol. 45, no. S1, pp. 74-76, 2017.

[9] F. H. An, Z. F. Wang, H. M. Yang et al., "Application of directional boreholes for gas drainage of adjacent seams," International Journal of Rock Mechanics and Mining Sciences, vol. 90, pp. 35-42, 2016.

[10] S. Q. Lu, Y. P. Cheng, J. M. Ma, and Y. B. Zhang, “Application of in-seam directional drilling technology for gas drainage with benefits to gas outburst control and greenhouse gas reductions in Daning coal mine, China," Natural Hazards, vol. 73, no. 3, pp. 1419-1437, 2014.

[11] Y. K. Li, S. Y. Wu, B. S. Nie, and Y. K. Ma, "A new pattern of underground space-time tridimensional gas drainage: a case study in Yuwu coal mine, China," Energy Science \& Engineering, vol. 7, no. 2, pp. 399-410, 2019.

[12] J. Liu, Z. G. Liu, K. Gao, and E. L. Jiang, "Application of deep borehole blasting to top-coal pre-weakening and gas extraction in fully mechanized caving," Chinese Journal of Rock Mechanics and Engineering, vol. 33, pp. 3361-3367, 2014.

[13] W. C. Zhu, C. H. Wei, S. Li, J. Wei, and M. S. Zhang, "Numerical modeling on destress blasting in coal seam for enhancing gas drainage," International Journal of Rock Mechanics and Mining Sciences, vol. 58, pp. 179-190, 2013.

[14] B. Bohloli and C. J. D. Pater, "Experimental study on hydraulic fracturing of soft rocks: influence of fluid rheology and confining stress," Journal of Petroleum Science and Engineering, vol. 53, no. 1-2, pp. 1-12, 2006.

[15] C. Z. Yan, H. Zhang, G. H. Sun, and X. R. Ge, "A 2d fdem-flow method for simulating hydraulic fracturing," Chinese Journal of Rock Mechanics and Engineering, vol. 1, pp. 67-75, 2015.
[16] D. Lockner and J. D. Byerlee, "Hydrofracture in Weber Sandstone at high confining pressure and differential stress," Journal of Geophysical Research, vol. 82, no. 14, pp. 2018-2026, 1977.

[17] J. Adachi, E. Siebrits, A. Peirce, and J. Desroches, "Computer simulation of hydraulic fractures," International Journal of Rock Mechanics and Mining Sciences, vol. 44, no. 5, pp. 739757, 2007.

[18] C. Zhai, X. Z. Li, and Q. G. Li, "Research and application of coal seam pulse hydraulic fracturing technology," Journal of China Coal Society, vol. 36, no. 12, pp. 1996-2001, 2011.

[19] Q. Li, B. Lin, and C. Zhai, "A new technique for preventing and controlling coal and gas outburst hazard with pulse hydraulic fracturing: a case study in Yuwu coal mine, China," Natural Hazards, vol. 75, no. 3, pp. 2931-2946, 2015.

[20] C. Zhai, M. Li, C. Sun, J. G. Zhang, W. Yang, and Q. G. Li, "Guiding-controlling technology of coal seam hydraulic fracturing fractures extension," International Journal of Mining Science \& Technology, vol. 22, no. 6, pp. 831-836, 2012.

[21] Q. Li, B. Lin, and C. Zhai, "The effect of pulse frequency on the fracture extension during hydraulic fracturing," Journal of Natural Gas Science and Engineering, vol. 21, pp. 296-303, 2014.

[22] W. Zhou, L. Yuan, G. L. Zhang et al., "A new method for determining the individual sources of goaf gas emissions: a case study in Sihe Coal Mine," Journal of China Coal Society, vol. 43, no. 4, pp. 1016-1023, 2018.

[23] Y. Xing and F. Zhang, "Optimizing borehole spacing for coal seam gas pre-drainage," Journal of Geophysics and Engineering, vol. 16, no. 2, pp. 399-410, 2019.

[24] M. K. Rahman and A. H. Joarder, "Investigating productioninduced stress change at fracture tips: Implications for a novel hydraulic fracturing technique," Journal of Petroleum Science and Engineering, vol. 51, no. 3-4, pp. 185-196, 2006.

[25] B. X. Huang, X. L. Zhao, S. L. Chen, and J. W. Liu, "Theory and technology of controlling hard roof with hydraulic fracturing in underground mining," Chinese Journal of Rock Mechanics and Engineering, vol. 36, no. 12, pp. 2954-2970, 2017.

[26] M. K. Hubbert and D. G. Willis, "Mechanics of hydraulic fracturing," Transactions of Society of petroleum engineers of AIME, vol. 210, pp. 153-168, 1957.

[27] B. Q. Lin, J. Meng, J. Ning, M. B. Zhang, Q. G. Li, and Y. Liu, "Research on dynamic characteristics of hydraulic fracturing in coal body containing gas," Journal of Mining and Safety Engineering, vol. 29, no. 1, pp. 106-110, 2012.

[28] B. X. Huang, C. Y. Liu, J. H. Fu, and H. Guan, "Hydraulic fracturing after water pressure control blasting for increased fracturing," International Journal of Rock Mechanics and Mining Sciences, vol. 48, no. 6, pp. 976-983, 2011.

[29] G. Li, C. A. Tang, L. C. Li, and Z. Z. Liang, "Numerical simulation of 3D hydraulic fracturing process," Chinese Journal of Geotechnical Engineering, vol. 32, no. 12, pp. 1875-1881, 2010.

[30] Y. Xue, J. Liu, P. G. Ranjith, X. Liang, and S. Wang, "Investigation of the influence of gas fracturing on fracturing characteristics of coal mass and gas extraction efficiency based on a multi-physical field model," Journal of Petroleum Science and Engineering, article, vol. 206, p. 109018, 2021.

[31] Y. X. Cao, J. S. Zhang, L. Tian, H. Zhai, G. T. Fu, and J. H. Tang, "Research and application of $\mathrm{CO}^{2}$ gas fracturing for gas control in low permeability coal seams," Journal of China Coal Society, vol. 42, no. 10, pp. 2631-2641, 2017. 
[32] B. Y. Jiang, S. T. Gu, L. G. Wang, G. C. Zhang, and W. S. Li, "Strainburst process of marble in tunnel-excavation-induced stress path considering intermediate principal stress," Journal of Central South University, vol. 26, no. 4, pp. 984-999, 2019.

[33] N. Jiang, D. W. Yin, J. B. Ma, L. Han, H. Y. Pan, and Q. Yin, "Effects of water immersion on the long-term bearing characteristics of crushed gangue in goaf," Geofluids, vol. 2021, Article ID 6675984, 2021.

[34] J. Wang, J. G. Ning, J. Q. Jiang, and T. T. Bu, "Structural characteristics of strata overlying of a fully mechanized longwall face: a case study," Journal of the South African Institute of Mining and Metallurgy, vol. 118, pp. 1195-1204, 2018.

[35] X. S. Liu, Y. L. Tan, J. G. Ning, Y. W. Lu, and Q. H. Gu, "Mechanical properties and damage constitutive model of coal in coal-rock combined body," International Journal of Rock Mechanics and Mining Sciences, vol. 110, pp. 140-150, 2018.

[36] W. Y. Guo, Y. L. Tan, F. H. Yu et al., "Mechanical behavior of rock-coal-rock specimens with different coal thicknesses," Geomechanics and Engineering, vol. 15, no. 4, pp. 1017-1027, 2018.

[37] K. Fang, T. B. Zhao, Y. B. Zhang, Y. Qiu, and J. H. Zhou, "Rock cone penetration test under lateral confining pressure," International Journal of Rock Mechanics and Mining Sciences, vol. 119, pp. 149-155, 2019.

[38] B. Q. Lin, S. N. Zhou, and R. G. Zhang, "Methane controlling technique at the upper corner of the goaf in u- type ventilation face," Journal of China Coal Society, vol. 22, no. 5, pp. 63-67, 1997.

[39] G. Wang, R. Wang, M. M. Wu, L. Xin, X. H. Zhou, and C. W. Liu, "Prevention and control technology of harmful gas intrusion in close-up coal seam under fire area," Journal of China Coal Society, vol. 42, no. 7, pp. 1765-1775, 2017. 